\title{
Editorial
}

Put Ang*, Jeong Ha Kim and Wendy Nelson

\section{A Festschrift in Honour of Prof. Robert E. DeWreede}

https://doi.org/10.1515/bot-2021-0080

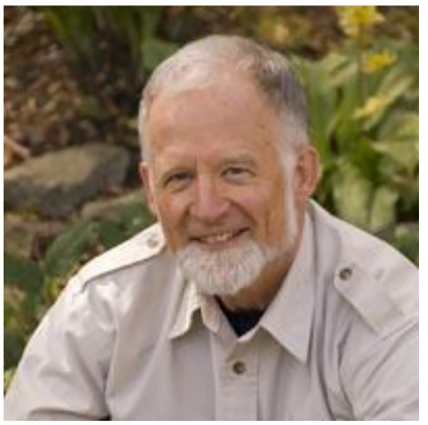

Photo courtesy of https://botany.ubc.ca/people/robert-dewreede

This special issue of Botanica Marina, with the theme "Changes in Marine Botanical Biodiversity and Ecology under Global Climate Change," is dedicated to Prof. Robert E. DeWreede on the occasion of his 80th birthday, January 24, 2021.

Rob is Professor Emeritus at the University of British Columbia (UBC), Department of Botany where he served as an Assistant Professor, Associate Professor and then as a Full Professor until his retirement in 2006.

In his early career, Rob worked with his $\mathrm{PhD}$ supervisor Prof. Maxwell Doty of the University of Hawaii to establish pilot farms for the red alga Eucheuma in the Philippines and the Confederated States of Micronesia. During his PhD and after joining the UBC Department of Botany, he devoted himself to research on macroalgal population and community ecology.

His research has focused on seaweed population dynamics, biomechanics and life history stage dynamics. In particular, he and his students have conducted extensive

*Corresponding author: Put Ang, Institute of Space and Earth Information Science, The Chinese University of Hong Kong, Hong Kong SAR, China, E-mail: aput96229@gmail.com

Jeong Ha Kim, Department of Biological Sciences, Sungkyunkwan University, Suwon, South Korea, E-mail: jhkbio@skku.edu Wendy Nelson, National Institute of Water and Atmospheric Research Ltd (NIWA), and School of Biological Sciences University of Auckland, Auckland, New Zealand, E-mail: wendy.nelson@auckland.ac.nz. https://orcid.org/0000-0003-0014-5560 field work on the population dynamics of the brown algae Analipus, Colpomenia, Egregia, Fucus, Hedophyllum, Laminaria, Pterygophora, and Sargassum, the red algae Lithothrix, Mazzaella, and Neorhodomela, and the green algae Acrosiphonia and Udotea. He pioneered work on the introduced species Sargassum muticum in British Columbia, Canada. He is one of the first to have discovered the presence of annual rings in Pterygophora and Laminaria and the application of this to algal population studies. He and his students have looked into age- and size-dependent mortality in Fucus. Contrary to theoretical predictions, his team found no significant differences in resource allocation to algal reproduction between closely related annual and perennial species and no evidence of a cost of reproduction in Fucus.

Rob's team also developed matrix models to describe the three main life history strategies of algae. These models have subsequently found meaningful application in addressing questions related to algal life history stage ratios, algal harvesting strategies and determining factors affecting algal survivorship under different environmental pressures.

Studies with clonal seaweeds revealed the importance of frond crowding for the reduction of desiccation and irradiance stress and related biomass losses in intertidal Mazzaella, although self-thinning was not observed, even during growth under high crowding levels, in a parallel with many clonal terrestrial plants.

Understanding biomechanics as a determinant of dynamics and life history stage abundance of algae is another long-time passion of Rob's. His team has examined wounding and wound healing in kelps like Pterygophora, blade tattering and holdfast integrity in Hedophyllum, the role of the holdfast as an anchoring structure in Laminaria and the effect of canopy cover on juvenile kelp recruitment and herbivore abundance. How blade surface area and thallus integrity could determine the survivorship of isomorphic life history stages of Mazzaella along a wave exposure gradient was also examined. Rob's team was the first to have documented the seasonal patterns in macroalgal attachment properties. Also for the first time, biomechanics was applied to the sand dwelling tropical coenocytic green alga Udotea, 
showing that this alga could be removed from the substrate entirely under high drag forces, although the water velocities required to generate this amount of drag occurred only under hurricane conditions. This outcome is in sharp contrast to those observed for other algae that are anchored to rock with their holdfasts.

At the community level, Rob and his team have explored the complex interactions between chitons, limpets, littorines, and barnacles in determining the structure of algal communities. The patterns of algal recolonization after a disturbance are mediated, in many cases predictably, through these interactions. The strength of these interactions may depend on the size of the interactors, whose roles or negative effects could be reversed as their sizes increased over time. Size was also observed as an escape mechanism of Hedophyllum from herbivory by chitons.

Rob's team also documented the relative importance of adult canopy and herbivory as a determinant of juvenile survivorship in Hedophyllum. More juveniles of this kelp survived on and among clumps of articulated coralline algae than on other surfaces, including surfaces of crustose coralline algae. The canopy of Hedophyllum could affect the abundance of chitons, which in turn could affect the survival of Hedophyllum recruits. On the other hand, changing seaweed assemblages have important effects on invertebrate epifauna diversity. This indicated how anthropogenic influences on seaweed assemblages could have significant impacts on the biodiversity of intertidal communities.

Seaweed life history dynamics is another area of algal research in Rob's lab. The mechanisms of temporal and ecological separation and the relative advantages of isomorphic life history stages of algae like Mazzaella were evaluated, to better understand how isomorphy in algae is being maintained. The relative complex life histories of brown algae like Analipus and Colpomenia were also assessed. Morphological variation between allegedly isomorphic life history stages may be manifested as differences in their survivorship. Some subtle biomechanical differences among the life history stages may also serve as a point for selection towards heteromorphy.

The complex life history of the filamentous green alga, Acrosiphonia, was also elucidated. DNA sequence data conclusively identified algal endophytes of the bladed red alga, Mazzaella splendens, and the crustose red alga, Mastocarpus, as alternate phases of Acrosiphonia, and field studies suggested a bet-hedging strategy for the two morphologically different phases adapted to a seasonally variable environment.

Rob's lab developed and refined a colorimetric resorcinol test to help differentiate the isomorphic life history stages of Mazzaella and other related species. Inexpensive water motion measurement devices and techniques and their utility in macroalgal ecology have also been assessed. These techniques are important to algal population and community studies. Furthermore, Rob's lab has also been engaged in other applied research, including evaluation of bioactive compounds in seaweeds, impact of acid mine drainage on Fucus populations, management issues related to marine protected areas and macrophyte ecology, and a baseline study of the interaction between seagrass and ghost shrimp. A taxonomic study on the diversity and distribution of seaweeds in northern Sulawesi, Indonesia, has also been carried out.

Rob has not only been deeply engaged in his research, but has always been a very dedicated teacher as well. Until recently, he continued to teach at the UBC Department of Botany even after his retirement. Rob is not only very supportive, caring and understanding to his graduate students, he is also well loved by his undergraduate students. Indeed, many of his students eventually took up careers in seaweed or environmentally related fields because of his influence and the role model he provided. His more than 20 graduate students and other associates came from around the world, including New Zealand, the Philippines/Hong Kong China, Indonesia, Korea, United Kingdom, Germany, Argentina, Mexico, USA and Canada and are now serving or have served in important positions as senior researchers, professors, or senior consultants, among others.

Rob has also been active in serving the international phycological communities. He is one of the founding organizers of the Northwest Algal Symposium. He served as the local co-chair of the 13th International Seaweed Symposium held in Vancouver, BC, in 1989. He also helped in the Asia Pacific Phycological Forum, gave a keynote speech and served as the editor of one of its proceedings. Through the Canadian International Development Agency, Rob also extended his services to help develop the marine biology programme in universities in Manado, North Sulawesi, Indonesia.

The theme of this special issue is in line with Rob's longtime research focus, with eight contributions from Rob's former students and colleagues. Both Sandra Lindstrom and Paul Gabrielson are former colleagues of Rob. Their papers, respectively on new and interesting chlorophytes from central coast of British Columbia, Canada and on reinstatement of Indian Ocean Porolithon coarctatum and P. gardineri with a description of a new species $P$. epiphyticum are important contributions to the documentation of algal biodiversity that serve as baseline information for any future changes. Wendy Nelson (Rob's first PhD student) and colleagues have updated the list of non-indigenous taxa recognized in New Zealand and consider global change drivers of algal range expansion or contraction. Jane Watson is Rob's former 
undergraduate student and Michael Hawkes is a former colleague. Their paper documents dynamics and disjunct distribution of the kelp Eisenia arborea along the west coast of Canada. David Garbary is Rob's former colleague and Herb Vandermeulen is a former $\mathrm{PhD}$ student. Their paper describes the increasing dominance of Fucus serratus along the Atlantic Coast of Nova Scotia, Canada. Both these two papers also consider how climate change might have driven the distribution pattern of the algal species observed. Ricardo Scrosati and Jeong Ha Kim are Rob's former PhD students. Ricardo's paper has investigated how macroalgal canopies could reduce beta diversity in intertidal communities and considers the utility of this diversity metric when investigating change within communities. The effects of sea urchin and herbivorous gastropod removal on algal transplants in seaweed forest restoration have been investigated in Jeong Ha Kim's paper, a very topical issue given increasing global interest in kelp bed restoration and the complex interactions between grazers, kelps and key climate change drivers. Finally, Terrie Klinger, Rob's first MS student, provides an insight into optimizing seaweed futures under climate change. Her paper aptly summarizes the ecological and industrial roles and limitations seaweeds play under climate change.

With this special issue, we as guest editors, together with all the contributors and other former students, would like to express our deep gratitude to Rob and to wish him good health, good cheer, and an enjoyable retirement!

\section{Wreede}

Representative publications of Robert E. De

- Anderson, K., Close, L., DeWreede, R.E., Lynch, B.J., Ormond, C. and Walker, M. (2006). Biomechanical properties and holdfast morphology of coenocytic algae (Halimedales, Chlorophyta) in Bocas del Toro, Panama. J. Exp. Mar. Biol. Ecol. 328: 155-167.

- Ang, P.O. Jr. and DeWreede, R.E. (1990). Matrix models for algal life history stages. Mar. Ecol. Prog. Ser. 59: 171-181.

- Ang, P.O. Jr. and DeWreede, R.E. (1992). Density dependence in a population of Fucus distichus. Mar. Ecol. Prog. Ser. 90: 169-181.

- Ang, P.O. Jr. and DeWreede, R.E. (1993). Simulation and analysis of the dynamics of a Fucus distichus (Phaeophyceae, Fucales) population. Mar. Ecol. Prog. Ser. 93: 253-265.

- Bates, C.R. and DeWreede R.E. (2007). Do changes in seaweed biodiversity influence invertebrate epifauna? J. Exp. Mar. Biol. Ecol. 344: 206-214.

- Biedka, R.F., Gosline, J.M. and DeWreede, R.E. (1987). Biomechanical analysis of wave-induced mortality in the marine alga Pterygophora californica. Mar. Ecol. Prog. Ser. 36: 163-170.
- Boizard, S.D. and DeWreede, R.E. (2006). Inexpensive water motion measurement devices and techniques and their utility in macroalgal ecology: a review. ScienceAsia 32 (Suppl. 1): 43-49.

- Chambers, P.A., DeWreede, R.E., Irlandi, E.A. and Vandermeulen, H. (1999). Management issues in macrophyte ecology: a Canadian perspective. Can. J. Bot. 77: 471-487.

- Collado-Vides, L.R., DeWreede, R.E. and Milligan, K.L.D. (1998). Biomechanical properties of Udotea (Halimedales, Chlorophyta) in a Mexican reef lagoon. Phycologia 37: 443-449.

- DeWreede, R.E. (1976). The phenology of three species of Sargassum (Sargassaceae, Phaeophyta) in Hawaii. Phycologia 15: 175-183.

- DeWreede, R.E. (1983). Sargassum muticum (Fucales, Phaeophyta) regrowth following disturbance, and interaction with Rhodomela larix (Ceramiales, Rhodophyta) in British Columbia. Phycologia 22: 153-160.

- DeWreede, R.E. (1984). Growth and age-class distribution of Pterygophora californica (Phaeophyta) in British Columbia, Canada. Mar. Ecol. Prog. Ser. 19: 93100.

- DeWreede, R.E. (1986). Demographic characteristics of Pterygophora californica (Laminariales, Phaeophyta). Phycologia 25: 11-17.

- DeWreede, R.E. and Green, L. (1990). Patterns of gametophyte dominance of Iridaea splendens (Rhodophyta) in Vancouver Harbor, Vancouver, British Columbia. J. Appl. Phycol. 2: 27-34.

- DeWreede, R.E. and Jones, E.C. (1973). New records of Sargassum hawaiiensis (Sargassaceae, Phaeophyta), a deep water species. Phycologia 12: 1-2.

- DeWreede, R.E. and Klinger, T. (1988). Reproductive strategies in algae. In: Lovett-Doust, J. and Lovett-Doust, L. (Eds.). Plant reproductive ecology: patterns and processes. Oxford University Press, Oxford, pp. 267-284.

- DeWreede, R.E., Ewanchuck, P. and Shaughnessy, F. (1992). Wounding, healing, and survivorship in three kelp species. Mar. Ecol. Prog. Ser. 82: 259-266.

- Dyck, L.J. and DeWreede, R.E. (1995). Patterns of seasonal demographic change in the alternate isomorphic stages of Mazzaella splendens (Gigartinales, Rhodophyta). Phycologia 34: 390-395.

- Dyck, L.J. and DeWreede, R.E. (2006b). Reproduction and survival in Mazzaella splendens (Gigartinales, Rhodophyta). Phycologia 45: 302-310.

- Garbary, D.J. and DeWreede, R.E. (1988). Life history phases in natural populations of Gigartinaceae (Rhodophyta): quantification using resorcinol. In: Lobban, C.S., Chapman, D.J. and Kremer, B.P. (Eds.). 
Experimental phycology: a laboratory manual. Cambridge University Press, New York, pp. 174-178.

- Gordon, D.K. and DeWreede, R.E. (1978). Factors influencing the distribution of Egregia menziesii (Turner) Areschoug (Phaeophyta, Laminariales) in British Columbia, Canada. Can. J. Bot. 56: 1198-1205.

- Kim J.H. and DeWreede, R.E. (1996a). Effects of size and season of disturbance on algal patch recovery in a rocky intertidal community. Mar. Ecol. Prog. Ser. 133: 217-228.

- Kim, J.H. and DeWreede, R.E. (1996b). Distribution and feeding preference of a high intertidal littorinid. Bot. Mar. 39: 561-569.

- Kim, J.H., Hudson, J.B., Huang, A.M., Bannister, K., Jin, H., Choi, T.J., Towers, G.H.N., Hong, Y.K., and DeWreede, R.E. (1997). Biological activities of seaweed extracts from British Columbia, Canada, and Korea: I. Antiviral Activity. Can. J. Bot. 75: 1656-1660.

- $\quad$ Klinger, T. and DeWreede, R.E. (1988). Stipe rings, age, and size in populations of Laminaria setchellii Silva (Laminariales, Phaeophyta) in British Columbia, Canada. Phycologia 27: 234-240.

- Markell, R. and DeWreede, R.E. (1998). Mechanisms underlying the effect of the chiton Katharina tunicata (Wood) on the kelp Hedophyllum sessile (C.Agardh) Setchell: size escape and indirect effects. Mar. Ecol. Prog. Ser. 166: 151-161.

- $\quad$ Marsden, A.D. and DeWreede, R.E. (2000). Community structure, reproductive function and metal content of marine intertidal algae near an acid mine drainage outflow. Environ. Poll. 110: 1-10.

- Marsden, A.D., DeWreede, R.E. and Levings, C. (2003). Survivorship and growth of Fucus gardneri after transplant to an acid mine drainage-polluted area. Mar. Pollut. Bull. 46: 65-73.

- Milligan, K.L.D. and DeWreede, R.E. (2000). Variations in holdfast attachment mechanics with developmental stage, substratum-type, season, and wave-exposure for the intertidal kelp species Hedophyllum sessile (C. Agardh) Setchell. J. Exp. Mar. Biol Ecol. 254: 189-209.

- Nelson, W.A. and DeWreede, R.E. (1989). Reproductive phenology of Analipus japonicus (Harv.) Wynne (Phaeophyta) in the eastern North Pacific. Jap. J. Phycol. 37: 53-56.

- Salomon, A.K., Ruesink, J.L. and DeWreede, R.E. (2006). Population viability, ecological processes and biodiversity: Valuing sites for reserve selection. Biol. Conserv. 128: 79-92.

- Scrosati, R. and DeWreede, R.E. (1997). Dynamics of the biomass-density relationship and frond biomass inequality for Mazzaella cornucopiae (Gigartinaceae,
Rhodophyta): implications for the understanding of frond interactions. Phycologia 36: 506-516 [Winner of the Canadian Botanical Association's J.S. Rowe Award for the Best Paper published by a student in Ecology in 1997].

- Scrosati, R. and DeWreede, R.E. (1998). Effects of frond crowding on frond bleaching in the clonal intertidal alga Mazzaella cornucopiae (Rhodophyta, Gigartinaceae) from British Columbia, Canada. J. Phycol. 34: 228-232.

- Shaughnessy, F.J. and DeWreede, R.E. (2001). Size, survival and the potential for reproduction in transplants of Mazaella splendens and Mazzaella linearis (Rhodophyta). Mar. Ecol. Prog. Ser. 222: 109-118.

- Shaughnessy, F.J., DeWreede, R.E. and Bell, E.C. (1996). Consequences of morphology and tissue strength to blade survivorship of two closely related Rhodophyta species. Mar. Ecol. Prog. Ser. 136: 257-266.

- Sussmann, A.V. and DeWreede, R.E. (2001). Life history of Acrosiphonia (Codiolales, Chlorophyta) in southwestern British Columbia, Canada. Am. J. Bot. 88: 1535-1544.

- Sussmann, A.V., Mable, B.K., DeWreede, R.E. and Berbee, M. (1999). Identification of green algal endophytes as the alternate phase of Acrosiphonia (Codiolales, Chlorophyta) using ITS1 and ITS2 ribosomal DNA sequence data. J. Phycol. 35: 607-614.

- Sussmann, A.V., Scrosati, R. and DeWreede, R.E. (2005). Seasonal synchrony of a green algal endophyte, Acrosiphonia (Codiolales), with its red algal hosts, Mastocarpus and Mazzaella (Gigartinales). Phycologia 44: 129-132.

- Vandermeulen, H. and DeWreede, R.E. (1986). The phenology, mortality, dispersal and canopy species interaction of Colpomenia peregrina (Sauv.) Hamel in British Columbia. J. Exp. Mar. Biol. Ecol. 99: 31-47.

- Vandermeulen, H. and DeWreede, R.E. (1987). Analysis of a population of Colpomenia peregrina in British Columbia: relationships with environment and primary substrate. Jap. J. Phycol. 35: 91-98.

Acknowledgements: Information in this guest editorial is partly taken from the home page of Robert E. DeWreede at the University of British Columbia (http://www3.botany. ubc.ca/phyclab/research.htm) with additional contributions from Rob's former students and colleagues.

Author contributions: All the authors have accepted responsibility for the entire content of this submitted manuscript and approved submission.

Research funding: None declared.

Conflict of interest statement: The authors declare no conflicts of interest regarding this article. 